1 Office of Populations, Censuses and Surveys. Mortality statistics 1983 England and Wales. London: HMSO, 1985. (DH1 No 14.)

2 Office of Populations, Censuses and Surveys. Mortality statistics England and Wales 1841-1980. London: HMSO, 1985. (Serial tables DH1 No 15.)

3 World Health Organisation. World healh statistics 1982: vital status and cause of death. Geneva WHO, 1982.

4 Retherford RD. Tobacco smoking and the sex mortality differential. Demography 1972;9:203-16 Waldron I. Type A behaviour pattern and coronary heart disease in men and women. Soc Sci Med 1978;12:167-70.

6 Burbank F. US lung cancer death rates begin to rise proportionately more rapidly for females than for males: a dose response effect. $f$ Chronic Dis 1972;25:473-9.

7 Office of Populations, Censuses and Surveys. General household survey 1982. London: HMSO, 1984.

8 Heller RF, Williams H, Sittampalam Y. Social class and ischaemic heart disease: use of the male:female ratio to identify possible occupational hazards. $\mathcal{f}$ Epidemiol Community Health 1984;38:198-202.

9 Barrett-Connor E, Khaw K-T. Family history of heart attack as an independent predictor of death due to cardiovascular disease. Circulation 1984;69:1065-9.

10 Silman AJ. Blood pressure in women: a separate case for treatment? Br Med f 1984;289:1021-2.

11 Wingard DL, Suarez L, Barrett-Connor E. The sex differential in mortality from all causes and ischaemic heart disease. Am f Epidemiol 1983;117:165-72.

12 Bayliss R, Clarke C, Whitefield AGW. The female life span. $f R$ Coll Physicians Lond 1986;20:290-3.

13 Stein Z, Maine D. The health of women. Int $f$ Epidemiol 1986;15:303-5.

14 Hazuda HP, Haffner SM, Stern MP, Knapp JA, Eifler CW, Rosenthal M. Employment status and woman's protection against coronary heart disease. Am f Epidemiol 1986;123:623-40. woman's protection against coronary heart disease. Am $\mathcal{F}$ Epidemio

15 Central Statistical Office. Social trends 1986. London: HMSO, 1986.

6 Centre For Disease Control. Acquired immunodeficiency syndrome (AIDS) among Blacks and Hispanics-United States. Morbidity and Mortality Weekly Report 1986;35:655-8.

17 Office of Populations, Censuses and Surveys. General household survey 1983. London: HMSO, 1985

18 Office of Populations, Censuses and Surveys, Cancer Research Campaign. Cancer statistics: incidence, survival and morality in England and Wales. London: HMSO, 1981. (Studies on Population and Medical Subjects No 43.)

19 Office of Populations, Censuses and Surveys, Department of Health and Social Security. Hospital in-patient enquiry 1984. London: HMSO, 1986. (MB4:25.)

20 Studd JWW, Thom MH. Ovarian failure and ageing. Clin Endocrinol Metab 1981;10:89-113.

21 Crilly RG, Francis RM, Nordin BEC. Steroid hormones', ageing and bone. Clin Endocrinol Metab 1981;10:115-39.

\section{Services for people with epilepsy}

Medical opinion no longer links epilepsy with onanism, and the lay notion of diabolic possession has been largely disabused, but those with epilepsy remain disadvantaged in many aspects of ordinary life. The International League Against Epilepsy, the British Epilepsy Association, the National Society for Epilepsy, and other groups and individuals have done much to dispel ignorance and myth-yet the approach to epilepsy of nurses, social workers, teachers, and employers is often unsatisfactory. Doctors too cannot escape censure: familiar still are the repeat prescriptions for inappropriate anticonvulsant polytherapy and the rare outpatient clinic review by often changing junior medical staff.

In 1969 services for people with epilepsy were reviewed in the comprehensive Reid report. ${ }^{1}$ On the initiative of the Department of Health and Social Security a working party was set up in 1983 to consider how much the Reid recommendations had been implemented, the impact of subsequent research (J D Morgan and A E Bennet, unpublished reports), and other developments. The conclusions of this group have now been published and should be carefully considered by all those caring for people with epilepsy. ${ }^{2}$

Many of the recommendations apply only to the comparatively few severely affected children and adults as these are the people most in need of special services. Much of the comment is, however, relevant to all those with epilepsy. Most will agree that it is no longer a counsel of perfection that all who have a seizure should be seen by a physician with an interest in epilepsy; usually this will be a neurologist or paediatrician with ready access to standard and specialised investigations. Most patients will then be cared for by their general practitioner, but many require continued hospital surveillance. The report makes a strong case for selected patients to be seen in epilepsy clinics. These clinics should link up with non-medical, statutory, and voluntary bodies; train postgraduates, undergraduates, and other interested groups; and participate in research. The prospect of the further proliferation of special district or supradistrict clinics is not universally popular, but setting up as an experiment a few model epilepsy clinics seems sensible. This might be done within existing facilities and with little additional expenditure.

The special schools and the special centres for the assessment, management, and rehabilitation of those with severe epilepsy are now well established, but their geographical distribution is unequal and the number of places inadequate. The working group recommends developing two new special assessment centres and an additional special centre for children. The Supraregional Services Advisory Group should be asked, it suggests, to designate those centres and encourage their direct funding by the Department of Health and Social Security. Only a few people with epilepsy require long term residential accommodation as distinct from a period of residential assessment and rehabilitation. These people may have associated mental subnormality and are best cared for within the mental handicap services. For the rest there is scope for improving the type of accommodation, the general facilities available, and the provision of transitional placement.

School leavers and adults with epilepsy know that their most difficult hurdles are related to employment. ${ }^{3}$ Grafted on to the traditional prejudices of employers and other employees is the modern bane of unemployment. The reality for young men and women with epilepsy, particularly in less privileged areas, is that the search for permanent employment is often unrewarding despite the best efforts of the career services, the Disablement Advisory Service, and the disablement resettlement officer. The statutory obligations are widely ignored, and doctors should inform, educate, and exhort local employers to achieve an unemployment rate among those with epilepsy no greater than that among others.

The reports of working parties often are merely a paper exercise and gather dust on departmental shelves. Furthermore, epilepsy has never been a fashionable disorder, often repelling rather than attracting the consideration, sympathy, and attention deserved. The present report should stimulate action from doctors and others concerned with epilepsy and from those officers at the health authorities and the Department of Health and Social Security who are responsible for resource allocation.

P K Newman

Consultant Neurologist,

Middlesbrough General Hospital,

Middlesbrough TS5 5AZ

1 Central Health Services Council, Advisory Committee on the Health and Welfare of Handicapped Persons. People with epilepsy. Report of a joint sub-committee of the Standing Medical Advisory Commitree and the Advisory Commitree on the Health and Welfare of Handicapped Persons. London HMSO, 1969.

2 Department of Health and Social Security. Report of the Working Group on Services for People with Epilepsy. A report to the Department of Health and Social Security, the Department of Education and Science, and the Welsh Office. London: HMSO, 1986.

3 Edwards F, Espir M, Oxley J, eds. Epilepsy and employment-a medical symposium on current problems and best practices. London: Royal Society of Medicine Services, 1986. (International Congress and Symposium Series No 86.) 